\title{
ANALISIS NILAI KEBERLANJUTAN PENGELOLAAN BENTANG ALAM PASCA TAMBANG BATUBARA PADA AREAL IZIN PINJAM PAKAI KAWASAN HUTAN
}

\author{
Value Analysis of Sustainable Landscape Management for Coal Post- \\ Mining At Lease-to-Use Forest Area Permit
}

\author{
ASEF K. HARDJANA ${ }^{1}$, HERRY PURNOMO ${ }^{2}$, DODIK R. NURROCHMAT ${ }^{2}$ dan IRDIKA MANSUR ${ }^{3}$ \\ ${ }^{1}$ Program Studi Pengelolaan Sumber Daya Alam dan Lingkungan, \\ Sekolah Pascasarjana Institut Pertanian Bogor \\ Kampus IPB Baranangsiang, Bogor 16151 \\ e-mail: akhardjana78@gmail.com \\ 2 Departemen Manajemen Hutan, Fakultas Kehutanan Institut Pertanian Bogor \\ Kampus IPB Dramaga, Bogor 16680 \\ ${ }^{3}$ Departemen Silvikultur, Fakultas Kehutanan Institut Pertanian Bogor \\ Kampus IPB Dramaga, Bogor 16680
}

\begin{abstract}
ABSTRAK
Penelitian ini dilakukan di lokasi perusahaan tambang batubara yang terdapat pada empat kabupaten, yaitu: Kutai Kartanegara, Kutai Timur, Kutai Barat dan Berau. Keempat daerah tersebut merupakan daerah tambang terbesar di Kalimantan Timur. Tujuan penelitian adalah menganalisis keberlanjutan pengelolaan bentang alam pasca tambang batubara di areal Izin Pinjam Pakai Kawasan Hutan (IPPKH) yang dikelola perusahaan berstatus usaha Perjanjian Karya Pengusahaan Pertambangan Batubara (PKP2B). Metodologi yang digunakan adalah multidimensional scaling (MDS) berdasarkan lima dimensi, yaitu: ekologi, ekonomi, sosial budaya, hukum dan kelembagaan, serta infrastruktur dan teknologi. Hasil penelitian menunjukan bahwa keberlanjutan pengelolaan bentang alam pasca tambang batubara di lokasi tersebut memiliki dua kategori status, yaitu: (1) status cukup berkelanjutan, terdiri dari: dimensi ekologi $(54,26)$, dimensi ekonomi $(55,06)$, dimensi hukum dan kelembagaan $(55,08)$, dimensi infrastuktur dan teknologi $(60,79)$; (2) status kurang berkelanjutan adalah dimensi sosial $(49,10)$. Terdapat 22 atribut yang dinilai sensitif (leverage attribute) bagi keberlanjutan pengelolaan bentang alam pasca tambang batubara pada kawasan tersebut, sehingga perlu diambil strategi kebijakan yang tepat untuk meningkatkan pengelolaannya, seperti melakukan rutinitas pengawasan, intervensi kebijakan dan perbaikan kinerja. Peran pemerintah sangat dibutuhkan di sini, agar strategi kebijakan memiliki kekuatan untuk ditaati dan fokus ke arah keberlanjutan bentang alam pasca tambang batubara di kawasan IPPKH.
\end{abstract}

Kata kunci: batubara, IPPKH, MDS, pasca tambang batubara, PKP2B

\section{ABSTRACT}

This research was conducted at the site of coal mining companies available at four districts, namely: Kutai Kartanegara, East Kutai, West Kutai and Berau, which are the largest mining areas in East Kalimantan. The objective is to analyze the sustainability of landscape management on coal post-mining land in the area of Forest Area Loan for Use Agreement (IPPKH) managed by a company with the status of a Concession Work 
Agreement (PKP2B). The used methodology is multi-dimensional scaling (MDS) based on five dimensions, namely: ecology, economy, social culture, law and institutions, and infrastructure and technology. The results showed that the sustainability of coal post-mining landscape management in this area has two status categories, namely: (1) sufficiently sustainable status, consisting of: ecological dimensions (54.26), economic dimensions (55.06), legal and institutional dimensions (55.08), infrastructure and technology dimensions (60.79); (2) unsustainable status is the social dimension (49.10). There are 22 attributes that are considered sensitive (leverage attribute) for the sustainability of coal post-mining landscape management in the area, so the right policy strategy needs to be taken to improve its management, such as conducting routine supervision, policy interventions and improving performance. The role of government is needed, so that the policy strategy has the power to be obeyed and focused towards the sustainability of the coal post-mining landscape in the IPPKH area.

Keywords: coal, IPPKH, MDS, coal post-mining, PKP2B

\section{PENDAHULUAN}

Pertambangan batubara merupakan seluruh tahapan kegiatan dalam rangka pengelolaan dan pengusahaan batubara yang meliputi pengamatan umum, kegeologian, eksplorasi, studi kelayakan, konstruksi, penambangan, pengolahan dan pemurnian, pengangkutan dan penjualan, serta kegiatan pasca tambang. Perkembangan pengusahaan pertambangan batubara memberikan jaminan yang cepat dan berkelanjutan kepada pembangunan ekonomi dan budaya masyarakat di sekitarnya (Dubiński, 2013). Namun, semakin meningkatnya eksploitasi terhadap batubara, menyebabkan kerusakan berat pada kawasan tambang dan sekitarnya. Lingkungan ekologi juga mengalami kerusakan terutama pada aktivitas tambang yang tidak ramah lingkungan (Ren-shu $d k k$., 2011). Beberapa tahun terakhir ini, karena eksploitasi yang berlebihan, membuat perubahan besar terhadap lingkungan ekologi di sekitar tambang, sehingga menimbulkan perubahan terhadap sifat-sifat fisik dan hayati lingkungan secara langsung atau tidak langsung, yang mengakibatkan fungsi lingkungan itu kurang atau tidak berfungsi lagi dalam menunjang pembangunan yang berkesinambungan (Pandey, Agrawal dan Singh, 2014; Dontala, Reddy dan Vadde, 2015).

Kegiatan pertambangan di kawasan hutan Indonesia menggunakan suatu izin khusus (IPPKH) yang tujuannya membatasi dan mengatur penggunaan sebagian kawasan hutan untuk kepentingan strategis atau kepentingan umum terbatas di luar sektor kehutanan tanpa mengubah status, fungsi, dan peruntukan kawasan hutan tersebut, serta menghindari terjadinya enclave di kawasan hutan (UndangUndang Republik Indonesia Nomor 41 Tahun 1999). Potensi batubara di kawasan hutan hanya dapat diberikan pada kawasan hutan produksi dan hutan lindung (Pasal 3(1) dan 4(2) Permen LHK Nomor P.27/Menlhk/Setjen/ Kum.1/7/2018). Merujuk data Kementerian Lingkungan Hidup dan Kehutanan sampai 2017, realisasi total luas kawasan hutan yang diberikan untuk IPPKH kepada perusahaan pertambangan mencapai kisaran 4.979.358,27 ha. Lahan seluas itu digunakan untuk survei/eksplorasi 4.481.580,52 ha dan $497.777,75$ ha untuk eksploitasi/operasi produksi (Kementerian Lingkungan Hidup dan Kehutanan, 2017).

Direktorat Jenderal Mineral dan Batubara (2017) menyebutkan bahwa sampai 2017, produksi batubara Indonesia mencapai 194.215,27 juta ton dengan jumlah batubara yang diekspor $131.639,00$ juta ton dan untuk kebutuhan domestik 74.419.710 ton. Provinsi Kalimantan Timur merupakan salah satu daerah penghasil batubara terbesar di Indonesia. Tercatat ada 1.170 perusahaan tambang batubara yang memiliki izin usaha pertambangan dengan produksi batubara 249.268,03 juta ton (Bidang Integrasi dan Diseminasi Statistik, 2018). Dari jumlah produksi tersebut, dibagi menjadi 2 (dua) sumber, yaitu: (1) perusahaan tambang batubara dengan Izin Usaha Pertambangan (IUP) yang dikeluarkan oleh Kepala Daerah/Kabupaten/Kota $86.101,65$ juta ton; dan (2) perusahaan tambang batubara dengan Perjanjian Karya Pengusahaan Pertambangan Batubara (PKP2B) 163.166,37 juta ton (Bidang Integrasi dan Diseminasi Statistik, 2018).

Dari jumlah tersebut ada 106 unit perusahaan tambang yang memiliki IPPKH di wilayah Kalimantan Timur. Untuk izin kegiatan survey/eksplorasi tambang di dalam kawasan hutan mencapai luasan 401.455,39 ha, sedangkan untuk eksploitasi/produksi tambang di dalam kawasan hutan mencapai luasan 
200.395,41 ha (Kementerian Lingkungan Hidup dan Kehutanan, 2017).

Tingginya aktivitas pertambangan dapat meningkatkan dampak kerusakan lingkungan, yang memberikan konsekuensi serius tidak hanya untuk daerah setempat tetapi juga wilayah secara global. Oleh karena itu pemanfaatan kawasan hutan di Kalimantan Timur untuk pertambangan perlu kehati-hatian. Semangat menggerakan ekonomi melalui aktivitas pertambangan dapat menghadirkan berbagai macam permasalahan bila tidak mengikuti pola pengelolaan hutan dengan baik.

Hutan dengan fungsi yang strategis tidak akan mampu kembali sebagaimana fungsinya dalam menyeimbangkan ekosistem bila kegiatan reklamasi kawasan hutan pasca tambang batubara tidak dilakukan dengan baik. Seperti di Provinsi Kalimantan Timur, luas kawasan hutan yang telah diberikan IPPKH untuk pertambangan batubara \pm 150.094,61 ha dan dari luasan tersebut terdapat kawasan hutan yang telah terbuka akibat aktivitas penambangan $\pm 32.986,61$ ha, namun hingga akhir tahun 2017 baru 43,88\% yang telah reklamasi (Diolah dari data Dirjen PDAS-HL Tahun 2018).
Penelitian ini bertujuan untuk menganalisis keberlanjutan pengelolaan bentang alam pasca tambang batubara di kawasan IPPKH yang dikelola oleh perusahaan tambang batubara dengan status usaha PKP2B di Kalimantan Timur ditinjau dari dimensi ekologi, ekonomi, sosial budaya, hukum dan kelembagaan serta infrastuktur dan teknologi. Dalam rangka keberlanjutan fungsi dan manfaat kawasan hutan pasca tambang batubara, agar tetap mampu menjaga kualitas sumberdaya alam dan kualitas budaya kehidupan masyarakat, serta dapat meningkatkan geliat perekonomian di sekitarnya, walaupun pengelolaannya nanti untuk pembangunan di luar sektor kehutanan.

\section{METODOLOGI}

\section{Lokasi dan Waktu}

Penelitian ini dilakukan di perusahaan tambang batubara dengan status usaha PKP2B yang berlokasi di Kabupaten Kutai Kartanegara (KTKK), Kutai Barat (KTKB), Kutai Timur (KTKT) dan Berau (KTBB) (Gambar 1). Data sekunder diambil di Jakarta, yaitu di Kementerian LHK dan ESDM. Penelitian dilakukan selama 12 bulan (April 2017- Maret 2018).

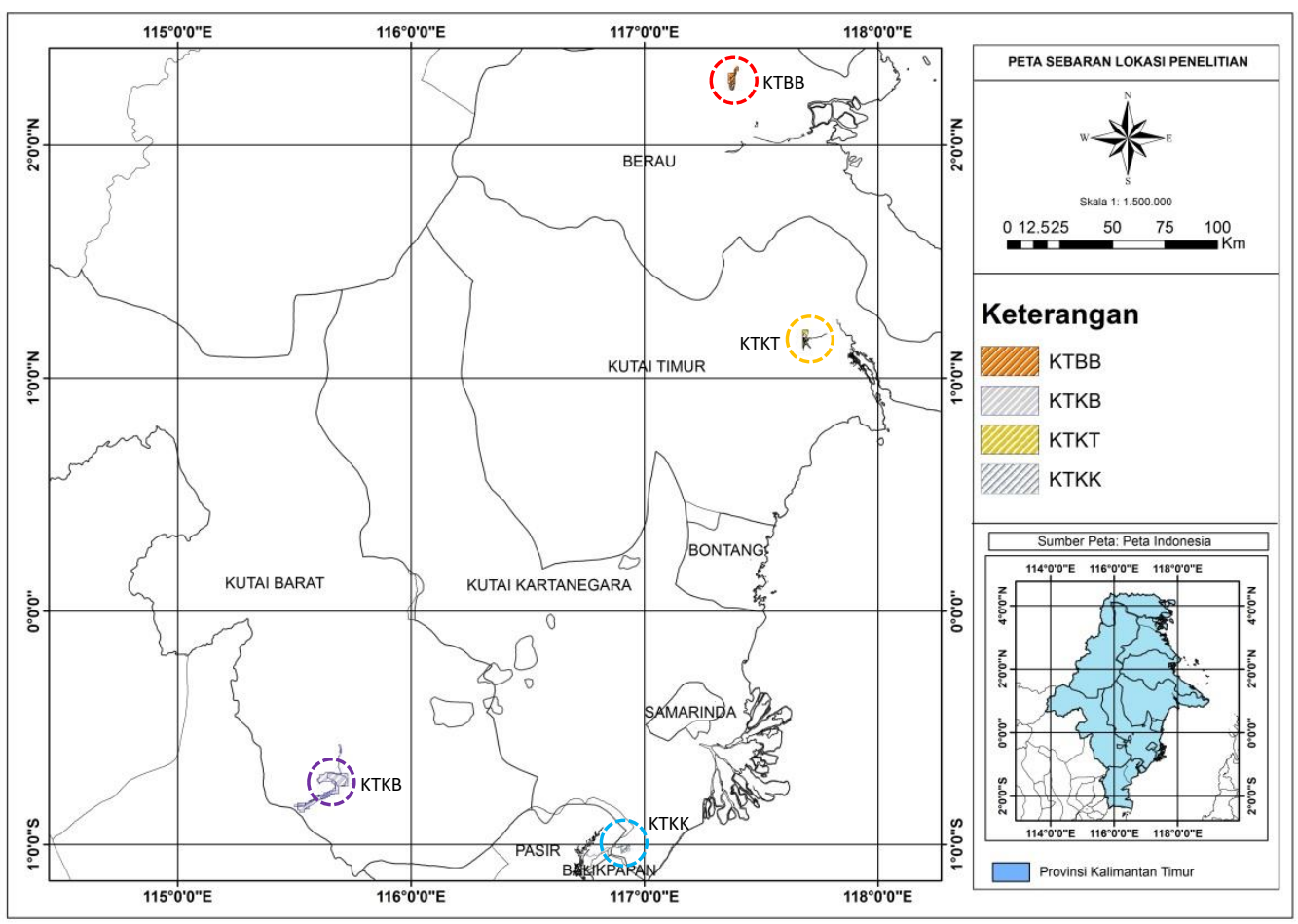

Gambar 1. Peta sebaran lokasi penelitian 


\section{Pengumpulan Data}

\section{Pengambilan data primer}

Pengambilan data primer dilakukan melalui survei responden dengan wawancara dan pengisian kuesioner. Responden adalah pelaku pertambangan pada 4 perusahaan tambang dengan status usaha PKP2B dan pelaku yang terkait dengan pertambangan batubara. Pengambilan data primer dilakukan secara langsung di lapangan, melalui pengamatan, pengisian kuisioner dan diskusi dengan Kepala Teknik Tambang (KTT), manajer teknis lapangan, masyarakat, serta diskusi dengan beberapa pakar terkait pemangku kepentingan, akademisi, birokrat dan pemerhati lingkungan).

\section{Pengambilan data sekunder}

Sebagian besar pengambilan data sekunder dilakukan di lokasi penelitian, seperti Dinas Kehutanan Provinsi Kalimantan Timur (Dishut Kaltim), Dinas Energi dan Sumber Daya Mineral Kalimantan Timur (Dinas ESDM Kaltim), Dinas Lingkungan Hidup Kalimantan Timur (DLH Kaltim), Badan Perencanaan Pembangunan Daerah Kalimantan Timur (BAPPEDA Kaltim), Balai Pemantapan Kawasan Hutan (BPKH) Samarinda, dan Balai Pengelolaan Daerah Aliran Sungai (BPDAS) Samarinda. Di samping itu pengambilan data sekunder juga dilakukan di Jakarta pada beberapa Kementerian dan Lembaga terkait.

Pemercontohan responden dari para pakar yang berperan sebagai narasumber kunci merupakan pemangku kepentingan yang ahli di bidangnya, baik yang berada di birokrasi atau pemerintah, akademisi dan unsur pemerhati lingkungan. Pemilihan narasumber dilakukan melalui teknik pemercontohan berantai (snowball sampling) (Subagyo, 2006). Kemudian pemercontohan responden dari masyarakat, dilakukan berdasarkan jarak aktivitas sehari-hari atau tempat tinggal dari kawasan pertambangan, sebagai pelengkap informasi dan klarifikasi atas hasil analisis narasumber kunci. Metode penentuan contoh dilakukan secara purposive pada semua reponden. Data yang digunakan berupa data primer dan sekunder. Data primer diperoleh dari wawancara yang dirancang sesuai dengan atribut masing-masing indikator dalam skala ordinal dari buruk hingga baik, sedangkan data sekunder berupa data laporan perusahaan tambang dan statistik dari lembaga terkait (Pitcher dkk., 2013).

\section{Prosedur Penelitian}

Penelitian ini menggunakan metode analisis ordinasi RAPCOAL (Rapid Appraisal for Coal Post-Mining) yang merupakan program modifikasi dari RAPFISH (Rapid Appraisal for Fisheries), melalui metode multi-dimensional scaling (MDS) untuk menilai indeks dan status keberlanjutan pengelolaan bentang alam pasca tambang batubara di areal IPPKH. Metode MDS ini dapat melakukan transformasi multi dimensi menjadi dimensi yang lebih sederhana (Fauzi dan Anna, 2005) dan mengidentifikasi atribut sensitif yang berpengaruh terhadap indeks keberlanjutan pengelolaan bentang alam pasca tambang melalui analisis leverage pada masing-masing dimensi. Dimensi yang dimaksud adalah dimensi ekologi, ekonomi, sosial dan budaya, hukum dan kelembagaan, infrastruktur dan teknologi.

Analisis ordinasi RAPCOAL dengan metode MDS dilakukan melalui beberapa tahapan yaitu: (1) penentuan atribut. Dalam penelitian ini ada 50 atribut yang mencakup 5 dimensi yaitu ekologi (10 atribut), ekonomi (10 atribut), sosial budaya (10 atribut), hukum dan kelembagaan (10 atribut), infrastruktur dan teknologi (10 atribut); (2) penilaian setiap atribut dalam skala ordinal (scoring) berdasarkan kriteria keberlanjutan setiap dimensi; (3) proses analisis menggunakan software SPSS untuk menentukan ordinasi dan nilai stress; (4) menilai indeks dan status keberlanjutan yang dikaji baik secara multidimensi maupun tiap dimensi; (5) analisis sensitifitas untuk menentukan peubah yang sensitif memengaruhi keberlanjutan; (6) analisis Monte Carlo untuk memperhitungkan aspek ketidakpastian (Kavanagh, 2001; Pitcher dan Preikshot, 2001).

Seluruh data dari atribut yang dipertimbangkan dalam penelitian ini selanjutnya dianalisis secara multidimensi untuk menentukan titik yang mencerminkan posisi keberlanjutan pengelolaan bentang alam pasca tambang pada masing-masing wilayah yang dikaji relatif terhadap dua titik acuan yaitu titik "baik" (good) dan titik "buruk" (bad). Posisi titik-titik keberlanjutan pembangunan ini secara visual akan sulit dibayangkan mengingat dimensinya 
sangat banyak. Oleh karena itu, untuk memudahkan visualisasi, digunakan analisis ordinasi dengan metode MDS (Nurmalina, 2008).

Dalam MDS, dua titik atau objek yang sama dipetakan dalam satu titik yang saling berdekatan. Sebaliknya, objek atau titik yang tidak sama digambarkan dengan titik-titik yang berjauhan. Titik-titik ini juga berguna dalam analisis regresi untuk menghitung "stress value" yang merupakan "nilai simpangan baku" metode MDS. Semakin kecil nilai stress (SStress) menunjukkan ketepatan analisis (goodness of fit) semakin baik, sedangkan nilai S-Stress yang tinggi menunjukkan sebaliknya (Fauzi dan Anna, 2005; Nababan, Sari dan Hermawan, 2017). Nilai stress terbesar yang masih dapat diterima adalah $25 \%$.

Melalui metode MDS, posisi titik keberlanjutan dapat divisualisasikan melalui sumbu horisontal dan vertikal, kemudian posisi indeks keberlanjutan dapat dirotasi pada sumbu horizontal. Indeks keberlanjutan adalah nilai masing-masing dimensi yang menggambarkan tingkat keberlanjutan (Sukwika dkk., 2018). Nilai indeks keberlanjutan ini disajikan pada Tabel 1.

Nilai indeks keberlanjutan masing-masing dimensi dapat divisualisasikan pada saat yang sama dalam bentuk diagram layang-layang, kondisi dan bentuk diagram tersebut ditentukan oleh indeks keberlanjutan setiap dimensi. Analisis atribut sensitif memiliki keunggulan untuk mengetahui atribut yang memberikan kontribusi terhadap nilai keberlanjutan sumber daya dan lingkungan, di samping itu digunakan untuk melihat perubahan atribut dalam output analisis MDS. Pengaruh setiap atribut terlihat dalam bentuk perubahan rootmean square (RMS), terutama pada sumbu $x$ untuk skala keberlanjutan dimensi sumber daya (Kavanagh dan Pitcher, 2004; Nurmalina, 2008; Sukwika dkk., 2018).

\section{HASIL DAN PEMBAHASAN}

Peraturan mengenai isu-isu lingkungan pasca tambang batubara di Indonesia sebagian besar mengimplementasikan peraturan-peraturan dari pengalaman negara lain. Tambang batubara harus memenuhi ketentuan terkait dengan lingkungan yang ditentukan dalam keputusan yang relevan dan izin administrasi, seperti di Uni Eropa, perlindungan lingkungan merupakan prioritas utama. Itulah sebabnya masalah yang penting untuk tambang batubara mengikuti persyaratan yang terkait dengan produksi batubara. Sejauh perlindungan lingkungan menjadi salah satu prioritas dalam strategi tambang batubara, dengan memperoleh volume produksi tertentu, kegiatan tambang batubara yang berat dapat meminimalkan dampak negatif terhadap lingkungan (Burchart-Korol dkk., 2014). Namun, kondisi tersebut berbeda dengan yang terdapat di Indonesia, strategi kebijakan dalam pengelolaan lingkungan di kawasan tambang batubara harus terlihat hasilnya. Untuk itu penilaian terhadap keberhasilan pengelolaan lingkungan pada kawasan tambang batubara ini, dapat dipantau dari keberhasilan suatu perusahaan tambang batubara dalam mengelola lingkungan pada lahan pasca tambangnya dalam menopang pembangunan berkelanjutan di sekitar areal tambang.

Mengingat pentingnya pemanfaatan berkelanjutan terhadap lahan pasca tambang, pemerintah Indonesia telah menerbitkan beberapa peraturan perundang-undangan yang berkaitan dengan kegiatan pertambangan. Peraturan Pemerintah Republik Indonesia Nomor 78 Tahun 2010 tentang reklamasi dan pasca tambang menyebutkan bahwa salah satu prinsipnya adalah perlindungan dan pengelolaan lingkungan hidup pertambangan, serta pemanfaatan lahan pasca tambang sebaiknya disesuaikan dengan tujuan penggunaannya.

Tabel 1. Kategori penilaian untuk analisis indeks dan status keberlanjutan.

\begin{tabular}{ccc}
\hline Skala Indeks & Kategori Status & Keterangan \\
\hline $00,00-25,00$ & buruk & tidak berkelanjutan \\
$25,01-50,00$ & kurang & kurang berkelanjutan \\
$50,01-75,00$ & cukup & cukup berkelanjutan \\
$75,01-100,00$ & baik & berkelanjutan \\
\hline
\end{tabular}

Sumber: Fauzi dan Anna (2005); Nurmalina (2008); Prasodjo dkk. (2015); Sukwika dkk. (2018). 
Isu kerusakan lingkungan pada 1960 telah menjadi perhatian dan mendapatkan respon dari pemerintahan setempat maupun lembaga dunia, seperti peristiwa eksploitasi hutan secara besar-besaran (dikenal dengan banjir cup) yang terjadi di Kalimantan Timur pada saat itu. Penerapan peraturan undang-undang terkait masalah pencemaran lingkungan pada waktu itu masih lemah dan kurang ditegakkan. Kemudian setelah bertahun-tahun, perdebatan terkait perlindungan lingkungan telah menjadi lebih fokus pada penipisan dan degradasi sumber daya alam, khususnya, air, udara, dan sumber daya tidak terbarukan (Bangian $d k k$., 2012). Istilah pembangunan berkelanjutan dirancang untuk mencerminkan keprihatinan ini, yang tumbuh dengan interaksi antara pertumbuhan ekonomi dan kualitas lingkungan jangka panjang. Pembangunan berkelanjutan merupakan pembangunan yang memenuhi kebutuhan sekarang tanpa mengurangi kemampuan generasi mendatang untuk memenuhi kebutuhan mereka sendiri (Kemp, Worden dan Owen, 2016).

\section{Keberlanjutan Dimensi Ekologi}

Bila ditinjau berdasarkan dimensi ekologi, maka lokasi perusahaan tambang PKP2B yang memiliki score keberlanjutan tertinggi dengan nilai 58,07 adalah di KTBB dengan kategori cukup berkelanjutan, disusul oleh KTKK dengan nilai 57,65 dengan kategori cukup berkelanjutan, kemudian KTKB dengan nilai 52,25 dengan kategori cukup berkelanjutan, serta KTKT dengan nilai 49,07 dengan kategori kurang berkelanjutan yang merupakan nilai terendah untuk dimensi ekologi (Gambar 2). Jika dirata-ratakan indeks keberlanjutan dimensi ekologi di kawasan tersebut adalah 54,26 dengan status kategori cukup berkelanjutan. Indeks tersebut lebih besar, bila dibandingkan hasil penelitian yang diperoleh Prasodjo dkk. (2015) pada wilayah Samarinda, Kalimantan Timur sebesar 45,35 dengan status kategori kurang berkelanjutan. Dilaporkan pula bahwa hasil penelitian keberlanjutan lahan pasca tambang batubara PT Kitadin, Kabupaten Kutai Kartanegara, Provinsi Kalimantan Timur memiliki nilai indeks keberlanjutan dimensi ekologi sebesar 60,11 artinya berstatus cukup berkelanjutan (Daru, Pagoray dan Suhardi, 2016).
Hasil analisis menunjukkan indeks keberlanjutan pengelolaan bentang alam pasca tambang batubara pada kawasan IPPKH di Kalimantan Timur, berdasarkan lokasi penelitian secara ekologi cukup berkelanjutan dimulai dari KTBB, kemudian disusul oleh KTKK dan KTKB, sedangkan KTKT dalam kondisi kurang berkelanjutan. Hal ini dapat dipahami karena dalam pengoperasian pertambangan ketiga lokasi PKP2B tersebut lebih dulu beroperasi dari KTKT, selain itu dengan lamanya beroperasi ketiga lokasi PKP2B ini lebih beragam dalam menghadapi permasalahan terkait ekologi dan selektif dalam mengambil keputusan dan tindakan dalam pemecahan masalah di lapangan khususnya terkait pengelolaan ekologi.

Namun terlepas dari hal di atas, konsekuensi kegiatan pertambangan akan membawa dampak terhadap lingkungan, baik positif maupun negatif. Konsep dasar pengelolaan pertambangan batubara hingga saat ini tidak banyak berubah; yang berubah hanyalah skala kegiatannya yang semakin luas dengan penambangan yang lebih dalam sehingga membawa dampak terhadap ekologi.

Berdasarkan hasil analisis sensitivitas, diperoleh nilai Root Mean Square (RMS) masing-masing atribut dimensi ekologi, seperti yang tersaji pada Gambar 2. Dari 10 atribut yang dianalisis ada 4 atribut utama yang mempunyai daya ungkit tinggi dan sensitif (nilai $\geq 0,60$ ) memengaruhi pengelolaan, yaitu: (1) konservasi dan penataan lahan terganggu; (2) gangguan terhadap ekosistem hutan; (3) ketersediaan dan kualitas air; (4) frekuensi kejadian banjir. Nilai RMS menunjukkan tingkat pengaruh atribut terhadap nilai indeks keberlanjutan. Atribut yang mempunyai pengaruh terbesar ditunjukkan dengan nilai RMS yang terbesar begitu juga sebaliknya atribut dengan nilai RMS terkecil mempunyai pengaruh yang kecil pula terhadap nilai indeks keberlanjutan (Wibowo, Anggoro dan Yulianto, 2015). Hal ini berarti bahwa dalam merumuskan kebijakan upaya meningkatkan status keberlanjutan dari dimensi ekologi perlu memperhatikan dan mempertimbangkan keempat atribut tersebut. 

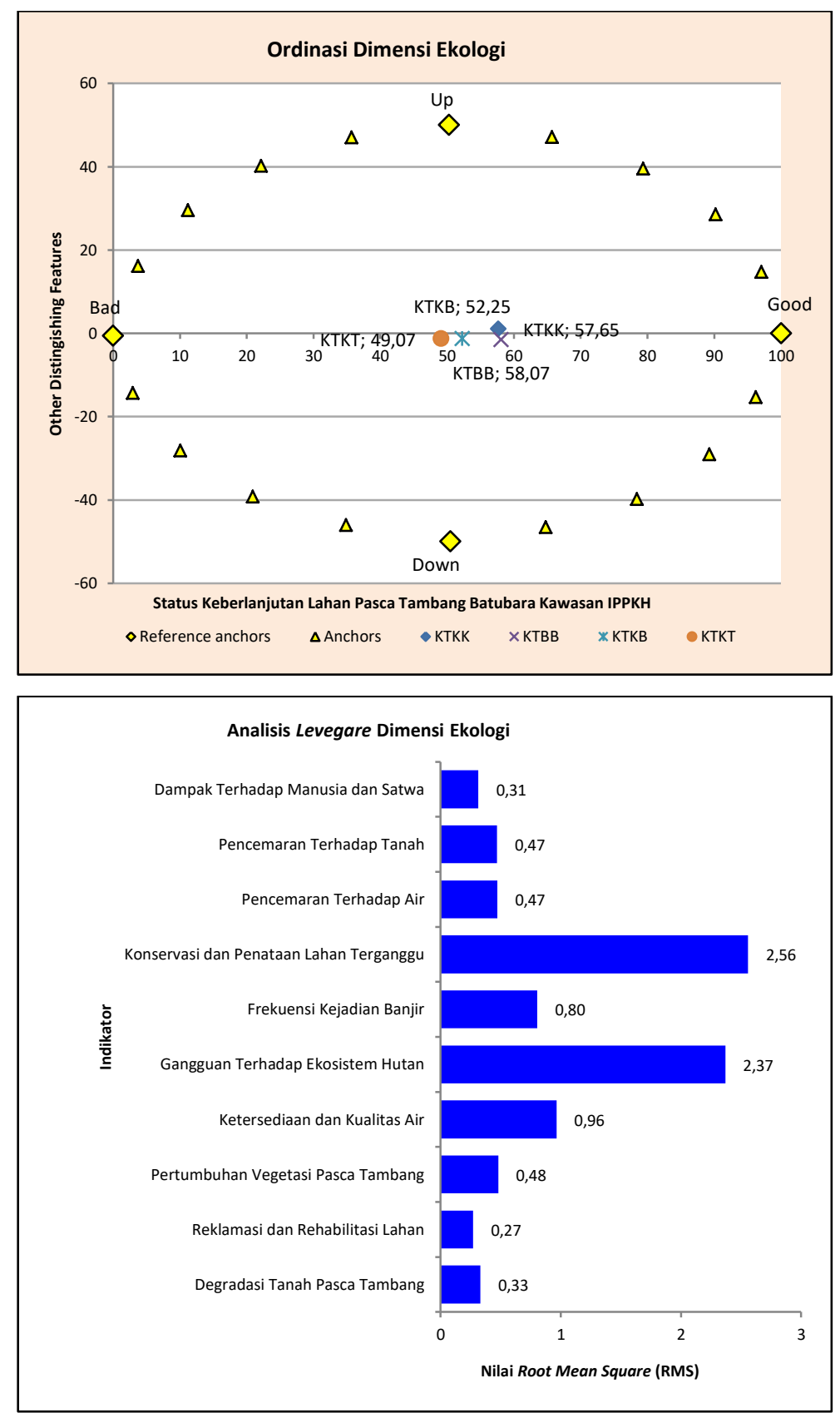

Gambar 2. Analisis indeks status keberlanjutan ekologi dan faktor sensitivitasnya yang memengaruhi pengelolaan bentang alam pasca tambang batubara pada kawasan IPPKH di Kalimantan Timur.

Faktor pengungkit ditentukan dari nilai RMS, atribut yang paling tinggi dibandingkan nilai atribut lainnya dalam dimensi ekologi. Sebagai faktor pengungkit, faktor-faktor ini berperan penting secara sensitif terhadap peningkatan atau penurunan nilai indeks keberlanjutan pengelolaan bentang alam pasca tambang batubara. Kegiatan pertambangan batubara mempunyai daya ubah lingkungan yang besar, sehingga memerlukan perencanaan total yang matang sejak tahap awal sampai pasca tambang. Seharusnya pada saat membuka tambang, sudah harus dipahami bagaimana menutup tambang dengan menyesuaikan tata guna lahan pasca tambang. Salah satu atribut kunci adalah kegiatan konservasi dan penataan lahan terganggu melalui upaya reklamasi dan revegetasi untuk meminimalkan kerusakan pada kawasan hutan pasca tambang batubara. 
Artinya atribut tersebut memberikan kontribusi yang baik terhadap status keberlanjutan dimensi ekologi. Tambang batubara yang dilakukan pada kawasan hutan menjadi salah satu gangguan serius terhadap ekosistemnya secara drastis yang mengarah kepada kerusakan lahan dan degradasi kawasan hutan. Dampak pertambangan memengaruhi potensi dan produktivitas lahan yang menyebabkan perubahan bentang alam, hilangnya struktur tegakan, peningkatan gas rumah kaca, penurunan produktivitas tanah karena perubahan sifat dan kondisi fisik, kimia dan biologi tanah, stabilitas tanah, erosi, sedimentasi dan banjir (Dubiński, 2013; Burchart-Korol dkk., 2014, 2016). Degradasi lahan ini lebih meningkat karena kurangnya penelitian, penanganan yang buruk, lemahnya regulasi dan kegagalan rehabilitasi lahan pasca tambang tersebut. Mengingat dampak pertambangan terhadap lingkungan pada kawasan hutan sangat membahayakan, sehingga lahan pasca tambang perlu direhabilitasi dengan melakukan reklamasi dan revegetasi. Untuk itu perlu dilakukan upaya-upaya dengan cara memelihara dan menjaganya serta memperbaharui teknologi yang ada.

Sementara itu, gangguan terhadap ekosistem hutan dirasakan sangat besar, sehingga untuk meningkatkan status keberlanjutan dimensi ekologi diperlukan upaya untuk meningkatkan status lahan sesuai fungsinya. Untuk itu operasional eksploitasi batubara disesuaikan dengan kemampuan lahannya, seperti pada tanah rawa-rawa, menggunakan perencanaan reklamasi dan penggunaan lahan yang berstatus rawan di kawasan pertambangan dengan melakukan reklamasi tanah, menjamin kelancaran aliran air, dan menghindari genangan air yang akan meningkatkan efisiensi penggunaan lahan (Ren-shu $d k k$., 2011; Huang $d k k ., \quad 2015)$. Prasodjo dkk. (2015) menyebutkan bahwa atribut pengungkit pada dimensi lingkungan hanya satu yaitu tingkat gangguan kegiatan pertambangan terhadap ekosistem, seperti hidrologi, erosi, flora, fauna, sifat fisika, dan kimia yang semuanya adalah aspek pengaruh ekosistem. Kegiatan penambangan selalu dikaitkan dengan pengaruh negatif yang ditimbulkannya terhadap lingkungan, mencegah dampak lingkungan yang signifikan menjadi lebih penting untuk tambang batubara. Menurut Burchart-Korol dkk. (2014, 2016) sebaiknya tambang batubara menerapkan sistem manajemen lingkungan dan mengembangkan strategi perlindungan lingkungan terhadap aspek utama pada lingkungan tambang batubara tersebut, seperti: perairan tambang, limbah pertambangan dan emisi metana ke atmosfer.

\section{Keberlanjutan Dimensi Ekonomi}

Gambar 3 menunjukkan indeks keberlanjutan dimensi ekonomi, dari nilai tertinggi 61,57 di KTBB, KTKK 57,55 dan di KTKB 53,23 dengan status kategori cukup berkelanjutan pada masing-masing PKP2B tersebut. Namun di wilayah KTKT indeks keberlanjutannya lebih rendah, yaitu sebesar 47,88 dengan status kategori kurang berkelanjutan. Jika dirata-ratakan indeks keberlanjutan dimensi ekonomi tersebut adalah 55,06 dengan status kategori cukup berkelanjutan. Indeks tersebut lebih besar, bila dibandingkan dengan hasil yang diperoleh oleh Prasodjo $d k k$. (2015) pada wilayah Samarinda, Kalimantan Timur sebesar 49,86 dengan status kategori kurang berkelanjutan.

Berdasarkan hasil analisis leverage seperti terlihat pada Gambar 3, dari 10 atribut yang dianalisis ada 5 atribut yang sensitif mempengaruhi besarnya indeks keberlanjutan dimensi ekonomi dengan nilai $\geq 0,60$ yaitu: (1) aktifitas ekonomi pasca tambang; (2) pengaruh terhadap pendapatan masyarakat; (3) nilai ekonomi lahan bekas tambang; (4) kontribusi pertambangan terhadap PDRB; pengembangan masyarakat dan ekonomi rakyat. Oleh karena itu, agar keberlanjutan dimensi ekonomi dalam 3 rangka pengelolaan bentang alam pasca tambang batubara pada kawasan IPPKH tercapai atau dapat ditingkatkan lagi, kelima atribut tersebut perlu diperhatikan dan dikelola dengan baik. 


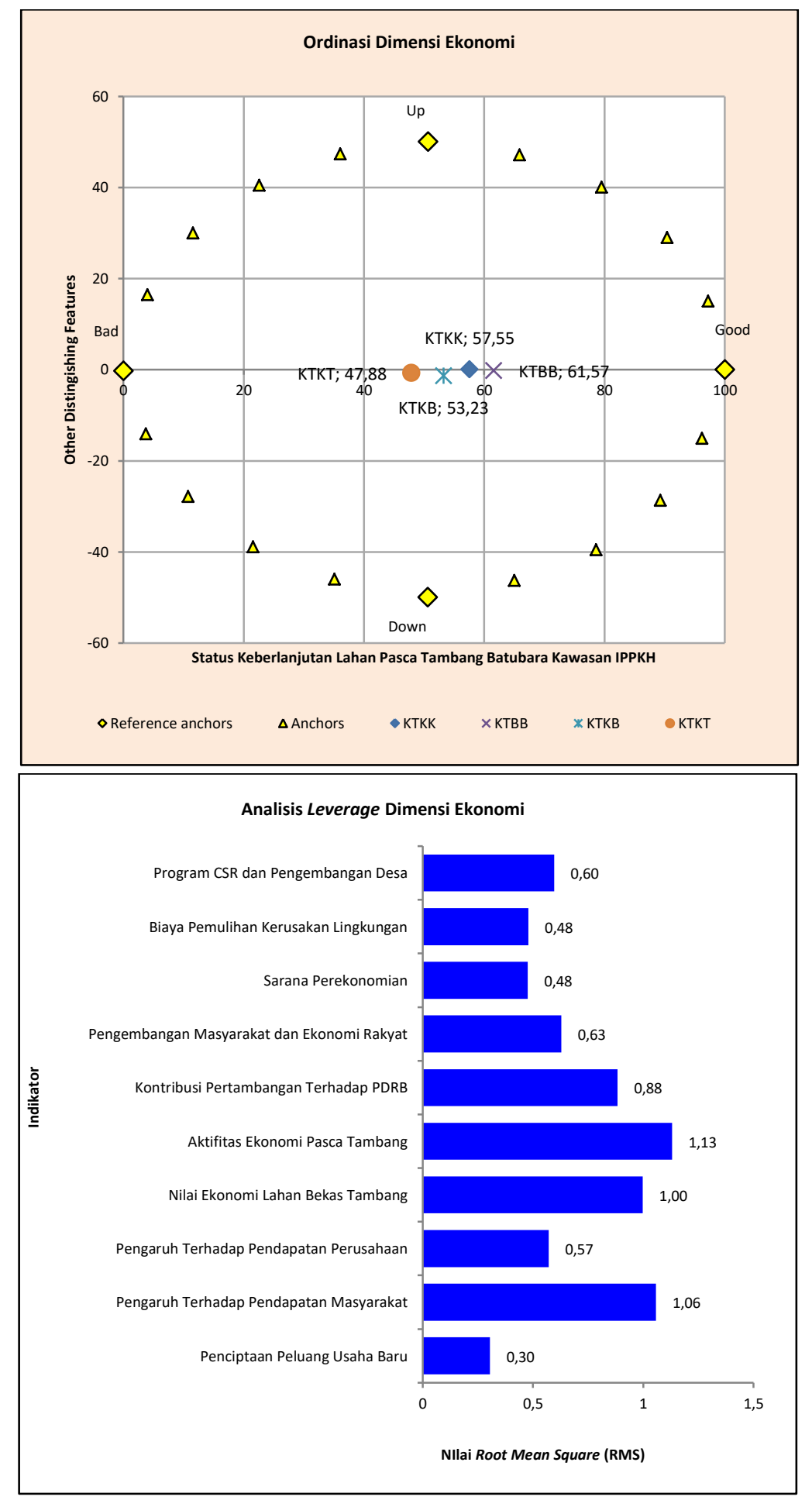

Gambar 3. Analisis indeks status keberlanjutan ekonomi dan faktor sensitivitasnya yang memengaruhi pengelolaan bentang alam pasca tambang batubara pada kawasan IPPKH di Kalimantan Timur.

Atribut aktivitas ekonomi pasca tambang merupakan atribut yang paling sensitif dalam keberlanjutan pengelolaan bentang alam hutan pasca tambang batubara untuk dimensi ekonomi, diikuti oleh atribut pengaruh terhadap pendapatan masyarakat. Dihubungkan dengan realita di lapangan, aktivitas ekonomi pasca tambang batubara secara langsung maupun tidak langsung berpegaruh terhadap pendapatan masyarakat di sekitar 
kawasan tambang. Pada kenyataannya, sebagian besar kegiatan pertambangan di Indonesia memiliki nilai manfaat positif, khususnya dari sisi keekonomian. Besarnya nilai manfaat tersebut dipengaruhi oleh fluktuasi harga batubara dari waktu ke waktu (Prasodjo dkk., 2015).

Kegiatan pasca tambang pada prinsipnya merupakan hal yang penting dalam konteks keberlanjutan kawasan pasca tambang yang harus dikembangkan ke kondisi yang produktif, melalui program reklamasi dan revegetasi. Kondisi akhir rehabilitasi dapat diarahkan sesuai dengan kesepakatan para pihak termasuk pengusaha, masyarakat setempat, pemerintah daerah dan pemerintah pusat (Prasodjo $d k k ., 2015)$. Aspek ekonomi yang sering menjadi perhatian untuk mencapai kesepakatan ini adalah eksistensi perusahaan tambang dan pengaruh terhadap pendapatan masyarakat setempat dari kegiatan pertambangan, sehingga keuntungan yang didapat dari kegiatan pertambangan batubara harus dapat ditransformasikan ke dalam kegiatan lain yang berkelanjutan terkait dengan aspek pengembangan masyarakat dan pelestarian lingkungan. Dari aspek ekonomi maupun manfaatnya, kegiatan pertambangan menunjukkan keseimbangan antara biaya eksternal yang dikeluarkan dan manfaat yang dihasilkan, seperti yang dikemukan oleh Krawczyk, Majer dan Krzemień (2014) serta Sierpińska dan Bąk (2012, 2013) di antaranya adalah:

1. Biaya kecelakaan kerja terkait;

2. Biaya penyakit akibat kerja;

3. Biaya kerusakan pertambangan dan hilangnya daerah terdegradasi oleh kegiatan penambangan (penurunan kegunaan dan nilai estetika suatu daerah);

4. Biaya lingkungan yang disebabkan oleh polusi emisi (limbah pertambangan terutama yang tidak terkelola, air tambang garam, metana);

5. Manfaat tempat kerja yang baru dibuat;

6. Manfaat kerja sama antara tambang batubara dan badan usaha lainnya;

7. Manfaat daerah dari penerimaan pajak.

Hasil wawancara dengan beberapa responden menyebutkan bahwa aktivitas kegiatan pertambangan batubara, berdampak positif terhadap aktivitas perekonomian di sekitar perkampungan mereka dan juga memberikan peningkatan pendapatan penduduk setempat. Pendapatan masyarakat setelah adanya kegiatan pertambangan rata-rata $\geq$ Rp. 2.650.000/KK/bulan dan ini melebihi angka kebutuhan hidup dengan upah minimum \pm Rp. 2.300.000/bulan. Meningkatnya pendapatan masyarakat dengan adanya kegiatan ini, berasal dari peluang usaha yang berkaitan erat dengan aktivitas tersebut, seperti:

1. Menjadi karyawan/buruh perusahaan, sebagai tenaga kerja lokal;

2. Membuka peluang usaha penunjang/jasa terhadap operasional penambangan, mulai dari pembukaan lahan, penggalian, transportasi, penjagaan/keamanan, reklamasi, rehabilitasi, dan lain-lain;

3. Program kemitraan dan pengembangan masyarakat melalui bimbingan usaha kecil, koperasi, pembangunan desa, serta menjadi pusat ekonomi pedesaan setempat;

4. Transparansi dalam ganti rugi pembebasan lahan antara perusahaan dan masyarakat (Prasodjo dkk., 2015).

\section{Keberlanjutan Dimensi Sosial Budaya}

Gambar 4 menunjukkan hasil analisis dimensi sosial budaya yang menunjukkan sebagian besar perusahaan tambang di lokasi penelitian termasuk ke dalam kategori kurang berkelanjutan dengan nilai rata-rata 49,10. Dimulai dari KTKT 44,68, KTKB 45,14 dan KTKK 47,82, sedangkan di lokasi KTBB memiliki indeks keberlanjutan 58,77 dengan status kategori cukup berkelanjutan. Tingginya nilai keberlanjutan di KTBB dibandingkan dengan 3 perusahaan lainnya merupakan hal yang cukup ideal, karena KTBB memiliki program pengembangan komunitas (community development - comdev) yang lebih baik. Program pengembangan komunitas di KTBB dilakukan melalui beberapa tahapan yaitu: periode giving (memberi) selama 5 tahun, involving (melibatkan) hingga tahun ke10, sharing (berbagi) hingga tahun ke-15, participating (berpartisipasi) hingga tahun ke20, dan sustainability (berkelanjutan). Selain itu pengembangan komunitas yang dilaksanakan ini menginvestasikan biaya yang cukup besar, agar pelaksanaannya dapat berjalan dengan lancar dan mencapai sasaran.

Berdasarkan hasil analisis leverage dapat diketahui bahwa atribut yang sensitif mempengaruhi besarnya indeks keberlanjutan 
dimensi sosial budaya adalah (1) peran pengembangan komunitas terhadap pembangunan masyarakat; (2) pengaruh tambang dengan nilai sosial budaya; (3) pemberdayaan masyarakat dalam pertambangan; (4) kesehatan masyarakat sekitar tambang; (5) penyerapan tenaga kerja. Kegiatan pengusahaan pertambangan batubara telah membuka lapangan kerja baru bagi masyarakat. Hal tersebut menyebabkan penurunan angka pengangguran di desa dan peningkatan pendapatan penduduknya. Jumlah tenaga kerja formal yang terserap di sektor pertambangan berkisar antara 20,3 $37,6 \%$ dari jumlah tenaga kerja produktif usia 15 tahun ke atas dan di bawah 55 tahun (Fauzi, 2007). Hasil penelitian lainnya juga menyebutkan bahwa penyerapan tenaga kerja dalam kegiatan pertambangan batubara merupakan dampak yang timbul pada aspek sosial yang berimplikasi pada aspek ekonomi yaitu terciptanya pendapatan masyarakat (Prasodjo dkk., 2015). Namun berbeda dengan hasil penelitian di atas, hasil penelitian ini menyebutkan bahwa penyerapan tenaga kerja menjadi peringkat ke-5 dalam hasil analisis leverage. Hal ini tidak lepas dari masih kurangnya perekrutan tenaga lokal, bahkan sebagian besar tenaga lokal banyak yang telah habis dan putus kontrak kerja, sehingga lebih banyak mengoptimalkan peran pengembangan komunitas dalam meredam gejolak maupun mengantisipasi konflik di masyarakat sekitar areal pertambangan.

Indeks keberlanjutan dimensi sosial budaya pada lokasi penelitian secara umum adalah 49,10 yang dapat dikategorikan sebagai kurang berkelanjutan. Atribut pengungkit yang berpengaruh adalah peran pengembangan komunitas terhadap pembangunan masyarakat, pengaruh tambang dengan nilai sosial budaya, pemberdayaan masyarakat dalam pertambangan. Tiga atribut ini terkait erat dalam menggerakkan pembangunan di sekitar pertambangan selama kegiatan pertambangan berlangsung. Kegiatan pertambangan seharusnya dapat menjadi penopang dalam pemberdayaan masyarakat di sekitar wilayah tersebut melalui kegiatan sosial dan kemitraan yang diharapkan akan membentuk hubungan harmonis antara perusahaan dengan masyarakat setempat.
Peran divisi pengembangan komunitas dalam pemberdayaan masyarakat lebih dioptimalkan sebagai bagian dari konsep penerapan corporate social responsibility (CSR) yang diatur dalam UU No. 4 tahun 2009 tentang Pertambangan Mineral dan Batubara. Kemudian UU tersebut diperjelas melalui turunan Permen ESDM RI No. 41 Tahun 2016 tentang Pengembangan dan Pemberdayaan Masyarakat pada Kegiatan Usaha Pertambangan Mineral dan Batubara. Oleh karena itu, program pengembangan masyarakat dilakukan pada seluruh tahapan kegiatan penambangan agar pengembangan sosial budaya dan lingkungan kehidupan masyarakat sekitar tambang dapat keberlanjutan.

\section{Keberlanjutan Dimensi Hukum dan Kelembagaan}

Hasil analisis dimensi hukum dan kelembagaan, menunjukkan status cukup berkelanjutan dengan nilai rata-rata 55,08 untuk semua perusahaan tambang yang menjadi objek penelitian, yaitu: KTKT 52,79, KTKB 53,80, KTKK 54,80 dan KTBB sebesar 58,94 yang memiliki indeks keberlanjutan tertinggi (Gambar 5). Status cukup berkelanjutan untuk dimensi hukum dan kelembagaan pada 4 lokasi tersebut karena sebagian besar permasalahan penegakan hukum terhadap pelanggaran lingkungan dan permasalahan ganti rugi lahan dapat diselesaikan secara baik.

Gambar 5 menunjukkan atribut sensitif yang memengaruhi besarnya indeks keberlanjutan dimensi hukum dan kelembagaan, yaitu: (1) penegakan hukum terhadap pelanggaran lingkungan; (2) persepsi terhadap IUP dan CnC; (3) ketersediaan aturan K3 dan lingkungan; (4) permasalahan ganti rugi lahan; (5) konflik dengan pemegang izin tambang lain. Penegakan hukum terhadap pelanggaran lingkungan amat penting, sehingga menjadi atribut yang paling sensitif dalam keberlanjutan dimensi hukum dan kelembagaan. Hal ini juga dikarenakan dalam prakteknya pelanggaran lingkungan oleh pemegang IPPKH masih sering terjadi, dan juga yang berkaitan dengan keberadaan tambang liar yang beroperasi di sekitar kawasan konsesi perusahaan tambang legal. Kasus pengambilan batubara oleh penambang 
liar sering terjadi di kawasan konsesi KTKK, dengan modus operasinya dilakukan pada malam hingga dini hari dan meninggalkan bekas bukaan permukaan tanah yang rusak berat. Hal ini akan merugikan pihak perusahaan pemilik konsesi bila dilakukan evaluasi dan pemantauan oleh pemerintah, karena dianggap lalai dan kurang pengawasan di areal konsesi yang dimilikinya. Untuk itu dihimbau melakukan tindakan penegakan hukum bekerjasama dengan aparat penegak hukum setempat sesuai aturan yang berlaku.
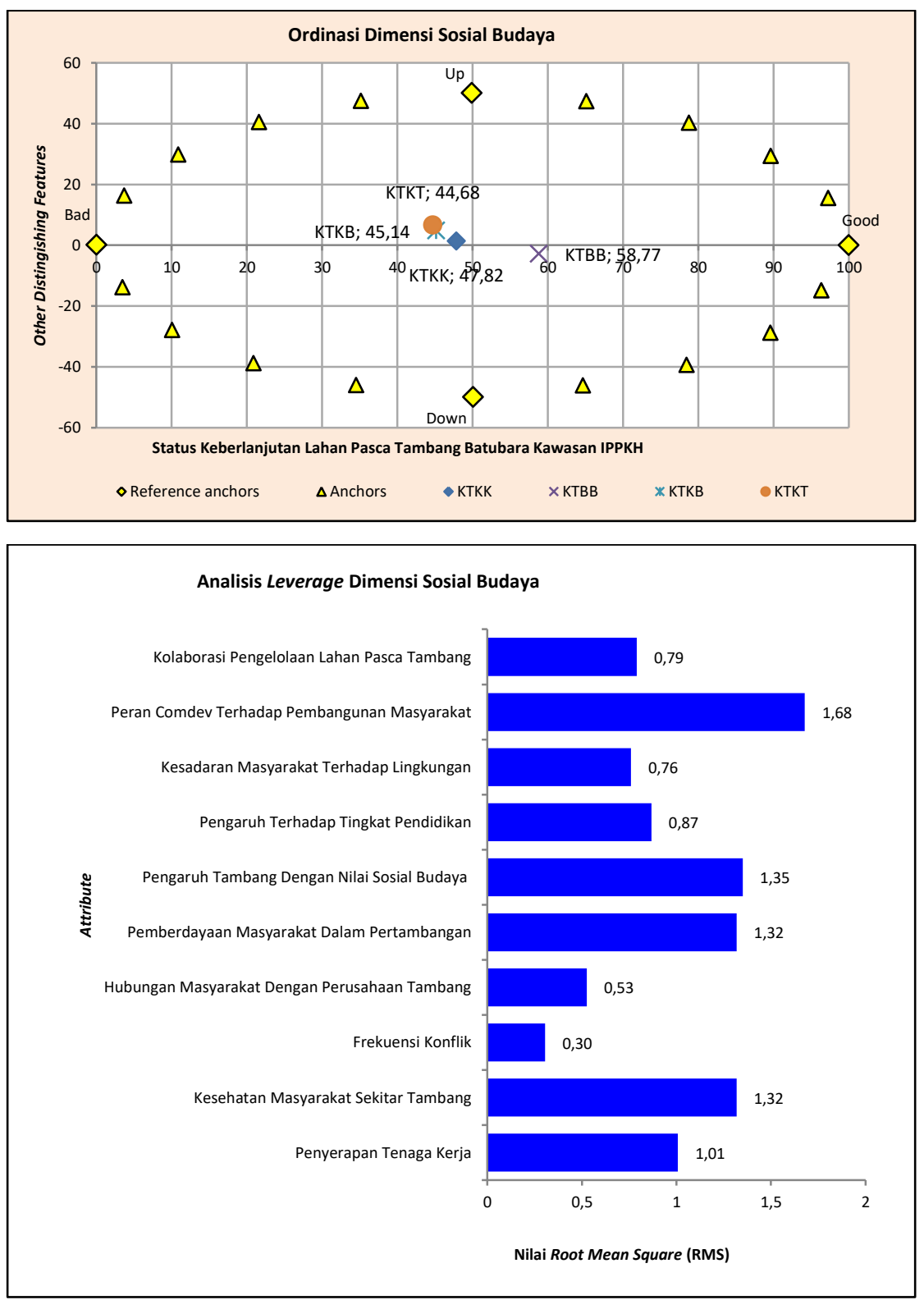

Gambar 4. Analisis indeks status keberlanjutan sosial budaya dan faktor sensitivitasnya yang memengaruhi pengelolaan bentang alam pasca tambang batubara pada kawasan IPPKH di Kalimantan Timur. 


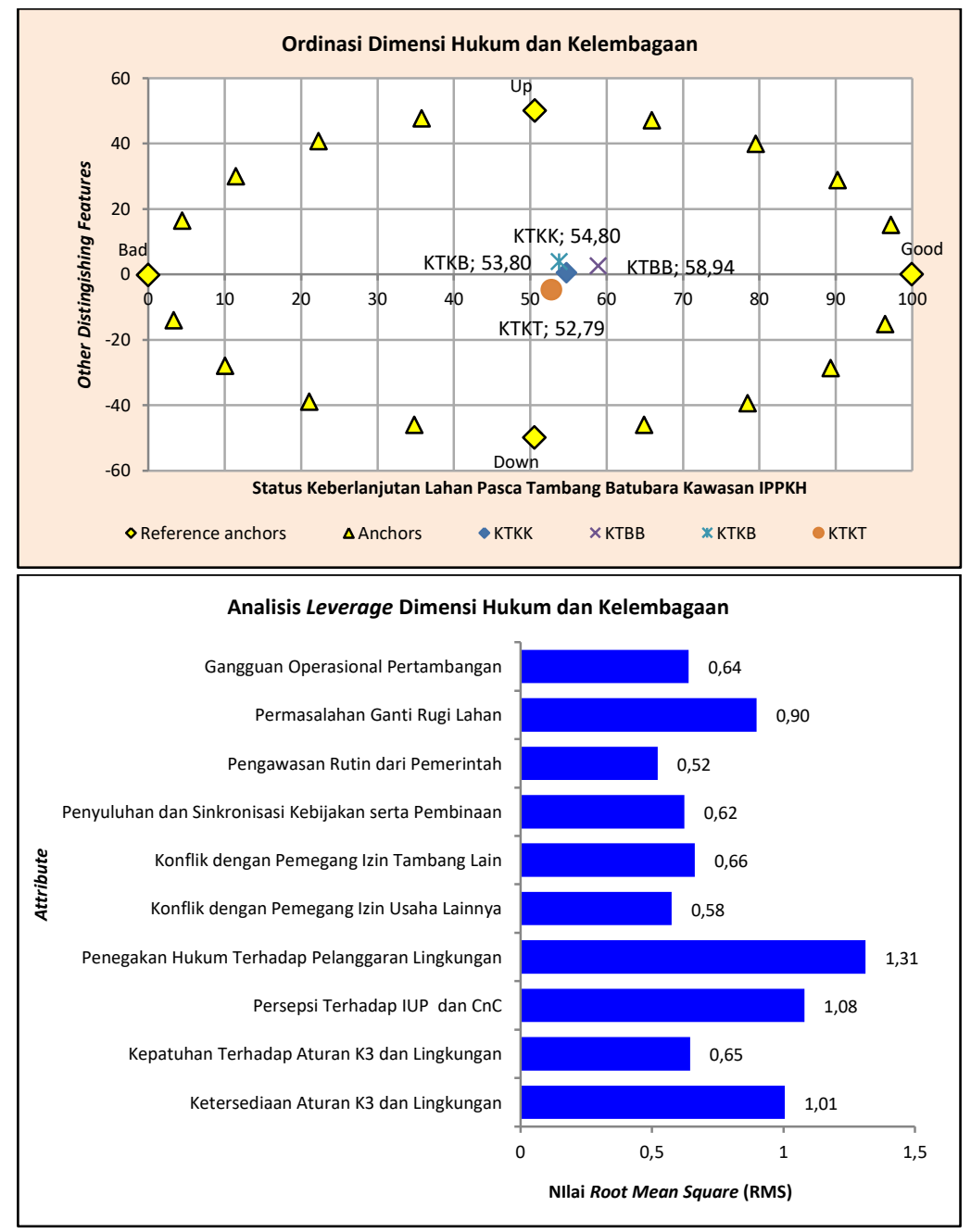

Gambar 5. Analisis indeks status keberlanjutan hukum dan kelembagaan serta faktor sensitivitasnya yang memengaruhi pengelolaan bentang alam pasca tambang batubara pada kawasan IPPKH di Kalimantan Timur.

\section{Keberlanjutan Dimensi Infrastuktur dan Teknologi}

Indeks keberlanjutan dimensi infrastruktur dan teknologi dalam rangka pengelolaan bentang alam pasca tambang batubara, termasuk dalam status cukup berkelanjutan dengan nilai rata-rata 60,79 untuk semua perusahaan tambang, mulai dari yang tertinggi yaitu: KTBB 67,82, KTKK 63,02, KTKB 58,15 dan KTKT 54,19 (Gambar 6). Status cukup berkelanjutan untuk dimensi infrastruktur dan teknologi ini merupakan dimensi yang memiliki nilai rata-rata tertinggi dari nilai indeks keberlanjutan dimensi ekologi, ekonomi, sosial budaya, maupun dimensi hukum dan kelembagaan. Hasil di atas mengandung pengertian bahwa pengelolaan bentang alam hutan pasca tambang batubara pada 4 lokasi tersebut ditinjau dari aspek infrastruktur dan teknologi lebih berkelanjutan dibandingkan dengan aspek ekologi, ekonomi, sosial budaya, serta hukum dan kelembagaan. Hal ini tidak lepas dari ketaatan untuk memenuhi aturan pembangunan infrastruktur pertambangan dan kemajuan serta kehandalan teknologi yang digunakan dalam operasional pertambangan sebagai upaya meminimalisasi kerusakan lingkungan.

Berdasarkan hasil analisis leverage, atribut yang sensitif mempengaruhi besarnya indeks keberlanjutan dimensi infrastruktur dan teknologi seperti yang tersaji pada Gambar 6 adalah (1) teknik pengelolaan lahan IPPKH; (2) keberadaan sarana prasarana pertambangan; (3) 
teknik rehabilitasi lahan pasca tambang; (4) pemanfaatan lahan pasca tambang; (5) pemahaman teknik pertambangan. Pemegang izin pertambangan, khususnya yang memiliki konsesi di kawasan hutan sebagian besar telah memahami pengelolaan lahan IPPKH yang dimulai dari proses perizinannya berdasarkan Permen LHK No. P.27 Tahun 2018, hingga proses reklamasi hutan berdasarkan Permenhut No. P.4 Tahun 2011. Hanya saja yang menjadi kurang baiknya pengelolaan lahan IPPKH di lapangan, kurangnya pengawasan pihak pemegang izin terhadap proses kegiatan yang dilakukan oleh pihak ketiga. Untuk itu di seluruh wilayah pertambangan perlu didukung dengan keberadaan para inspektur tambang dan petugas pengendali ekosistem hutan yang memiliki kewenangan mulai dari pengawasan, pemantauan, dan penindakan sampai kepada penghentian operasi sementara terhadap tambang yang melanggar ketentuan lingkungan maupun kehutanan seperti pelanggaran ketentuan tingkat operasi produksi, kegiatan reklamasi dan lain-lain. Selain itu, dari pihak perusahaan tambang sendiri juga perlu memberdayakan peran divisi environment secara maksimal dalam melakukan pengawasan terhadap teknik pengelolaan lahan IPPKH selama proses penambangan hingga perapihannya, terutama dalam proses pembukaan kawasan, operasi produksi, reklamasi dan pengendalian kerusakan lingkungan lainnya.

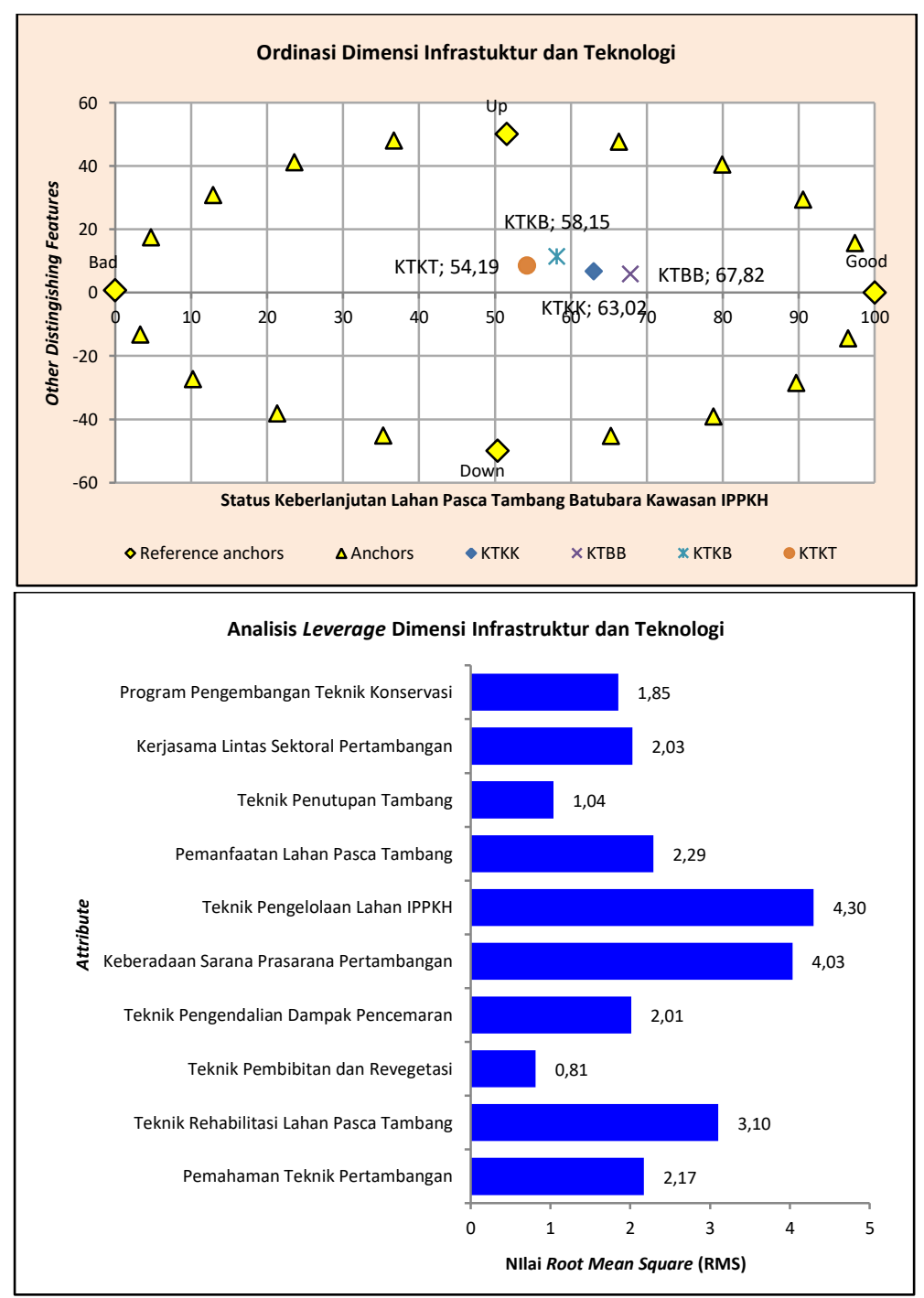

Gambar 6. Analisis indeks status keberlanjutan infrastruktur dan teknologi serta faktor sensitivitasnya yang memengaruhi pengelolaan bentang alam pasca tambang batubara pada kawasan IPPKH di Kalimantan Timur. 
Fasilitas sarana dan prasarana untuk mendukung kegiatan pertambangan menjadi hal yang wajib bagi pemegang izin pertambangan, serta tidak diperkenankan untuk menggunakan fasilitas umum seperti jalan raya dan pelabuhan umum (Prasodjo $d k k ., 2015)$, namun sebaliknya pemegang izin dihimbau untuk membangun fasilitas sarana dan prasarana untuk kepentingan masyarakat sekitarnya. Karena keberadaan sarana dan prasarana umum ini dapat menimbulkan persepsi yang baik dari masyarakat kepada pihak perusahaan dan juga dapat menimbulkan dampak lingkungan, ekonomi dan sosial, baik yang kearah positif maupun arah negatif.

\section{Analisis RAPCOAL dan Monte Carlo}

Hasil analisis RAPCOAL pada kelima dimensi keberlanjutan pengelolaan bentang alam pasca tambang batubara pada kawasan IPPKH di Kalimantan Timur memiliki rataan nilai indeks keberlanjutan secara berurutan sebesar 54,26 untuk dimensi ekologi, 55,06 untuk dimensi ekonomi, 49,10 untuk dimensi sosial budaya, 55,08 untuk dimensi hukum dan kelembagaan, 60,79 untuk dimensi infrastuktur dan teknologi. Dari nilai indeks keberlanjutan tersebut menunjukan 4 dimensi termasuk dalam kategori status cukup berkelanjutan, satu dimensi dengan status kurang berkelanjutan dan tidak ada satu pun dimensi yang termasuk kategori buruk atau tidak berkelanjutan.
Nilai indeks keberlanjutan untuk setiap dimensi ini dapat digambarkan dalam bentuk diagram layang seperti yang terlihat pada Gambar 7. Berdasarkan diagram tersebut dapat diketahui bahwa berbagai kondisi perusahaan tambang batubara dengan status usaha PKP2B memiliki prioritas pengelolaan dimensi yang berbeda, dimensi mana yang harus lebih diutamakan untuk menjadi perhatian agar dimensi tersebut berada pada kategori "baik" atau paling tidak "cukup". Berdasarkan diagram pada Gambar 7 tersebut, diketahui bahwa dimensi yang perlu diprioritaskan untuk ditingkatkan adalah dimensi sosial budaya, khususnya pada 4 lokasi perusahaan tambang batubara karena nilai indeksnya di bawah skor 50 pada skala berkelanjutan 0 - 100, sehingga dikategorikan sebagai kurang berkelanjutan.

Strategi kebijakan yang perlu dilakukan adalah dengan mengelola keempat faktor sensitivitasnya yaitu dengan (1) meningkatkan aktivitas ekonomi pasca tambang; (2) meningkatkan pengaruh terhadap pendapatan masyarakat; (3) memperhatikan nilai ekonomi lahan bekas tambang; (4) meningkatkan kontribusi pertambangan terhadap PDRB; (5) memacu pengembangan masyarakat dan ekonomi rakyat.

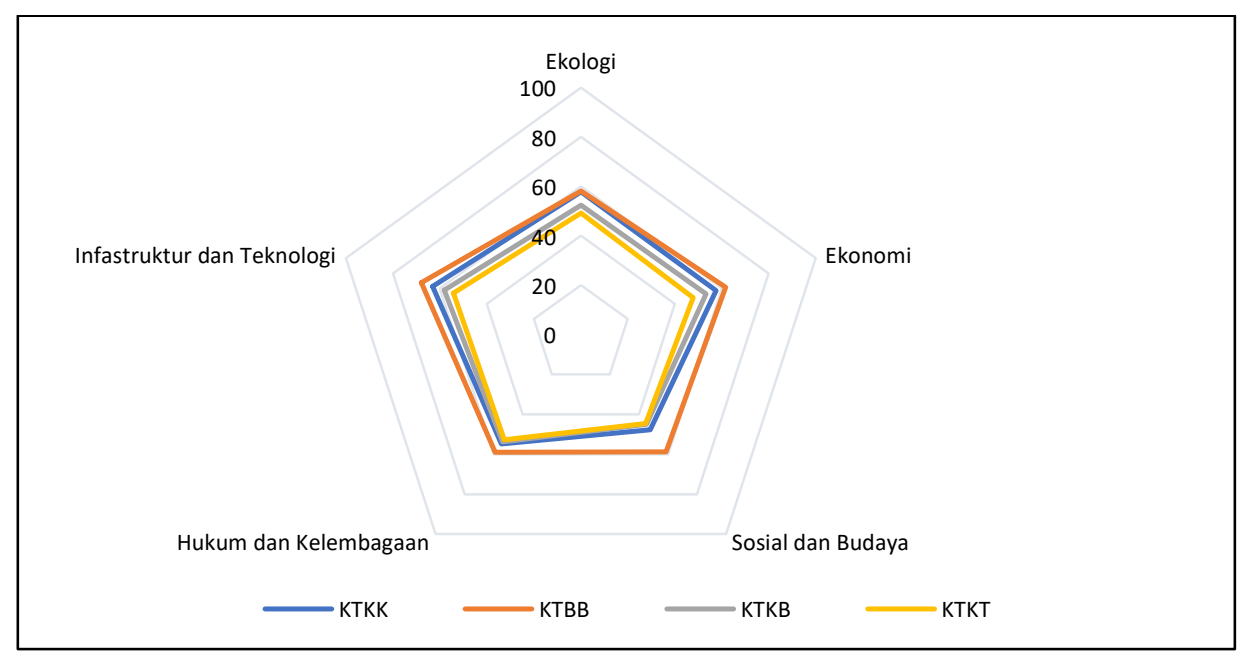

Gambar 7. Diagram layang status keberlanjutan pengelolaan bentang alam pasca tambang batubara pada kawasan IPPKH di Kalimantan Timur. 
Prioritas kedua adalah dengan meningkatkan nilai indeks keberlanjutan dimensi ekologi, walaupun statusnya cukup keberlanjutan, namun berada pada urutan terakhir sebagai dimensi yang berstatus cukup keberlanjutan.

Hal yang dilakukan untuk meningkatkan indeks status keberlanjutannya adalah mengelola faktor sensitivitasnya dengan cara: (1) memperhatikan konservasi dan penataan lahan terganggu; (2) meminimalkan gangguan terhadap ekosistem hutan; (3) menjaga ketersediaan dan kualitas air; meminimalisasi frekuensi kejadian banjir.

Dari hasil analisis RAPCOAL, nilai S-Stress yang diperoleh antara 0,158-0,188. Secara multidimensi diperoleh nilai sebesar 0,181. Nilai S-Stress tersebut lebih kecil dari 0,25, menunjukkan bahwa model analisis MDS yang diterapkan memiliki ketepatan yang tinggi (goodness of fit). Hasil analisis tersebut juga menunjukan nilai koefisien determinasi $\left(R^{2}\right)$ antara 0,934-0,950 dan nilai $R^{2}$ multidimensi diperoleh sebesar 0,938 atau mendekati nilai 1. Dengan demikian dari kedua parameter statistik ini menunjukkan bahwa seluruh atribut yang digunakan pada setiap dimensi sudah cukup baik menerangkan keberlanjutan pengelolaan bentang alam pasca tambang batubara pada kawasan IPPKH di lokasi penelitian. Dengan demikian model pendugaan indeks keberlanjutan cukup memadai untuk digunakan (Pitcher $d k k$., 2013). Nilai S-stress dan koefisien determinasi $\left(R^{2}\right)$ hasil analisis RAPCOAL disajikan pada Tabel 2.

Tabel 3 menunjukan perbandingan hasil analisis MDS dengan Monte Carlo pada taraf kepercayaan 95\%. Dengan kata lain, tingkat kepercayaan terhadap indeks total (multidimensi) terhadap indeks setiap dimensi lebih dari 95\%. Ini berarti bahwa model analisis MDS yang dihasilkan memadai dan menunjukkan bahwa sistem yang dikaji memiliki tingkat kepercayaan yang tinggi dalam menduga keberlanjutan pengelolaan bentang alam pasca tambang batubara pada kawasan IPPKH di lokasi penelitian. Beda nilai yang kecil juga menunjukkan bahwa pengaruh kesalahan terhadap pembuatan skor pada setiap atribut, kesalahan yang diakibatkan karena kurangnya pemahaman, perbedaan opini, atau penilaian dari peneliti yang saling berbeda, kesalahan pemasukan data atau data yang hilang, dan kesalahan posedur yang dapat memengaruhi stabilitas proses analisis MDS, relatif kecil (Widiatmaka $d k k$., 2015). Hasil uji statistik ini menunjukkan bahwa metode RAPCOAL cukup baik untuk dipergunakan sebagai salah satu alat evaluasi keberlanjutan pengelolaan bentang alam pasca tambang batubara pada kawasan IPPKH di Kalimantan Timur.

Tabel 2. Parameter statistik analisis RAPCOAL dengan metode MDS pada setiap dimensi keberlanjutan pengelolaan bentang alam pasca tambang batubara pada kawasan IPPKH di Kalimantan Timur.

\begin{tabular}{cccccc}
\hline \multirow{2}{*}{ Paramater Statistik } & \multicolumn{4}{c}{ Dimensi Keberlanjutan } \\
\cline { 2 - 6 } & Ekologi & Ekonomi & Sosial Budaya & Hukum \& Kelembagaan & Infrastuktur \& Teknologi \\
\hline Nilai Stress $(\mathrm{S})$ & 0,187 & 0,188 & 0,185 & 0,188 & 0,158 \\
R-squared $\left(\mathrm{R}^{2}\right)$ & 0,936 & 0,934 & 0,935 & 0,935 & 0,950 \\
\hline
\end{tabular}

Tabel 3. Hasil analisis Monte Carlo multidimensi dan masing-masing dimensi keberlanjutan untuk nilai RAPCOAL dengan selang kepercayaan 95\%.

\begin{tabular}{lccc}
\hline & & & Indeks Keberlanjutan \\
\cline { 2 - 4 } \multicolumn{1}{c}{ Dimensi } & MDS & Monte Carlo & Perbedaan \\
\hline Ekologi & 54,261 & 54,352 & $-0,091$ \\
Ekonomi & 55,059 & 55,276 & $-0,217$ \\
Sosial Budaya & 49,101 & 49,084 & 0,017 \\
Hukum dan Kelembagaan & 55,082 & 55,087 & $-0,005$ \\
Infrastuktur dan Teknologi & 60,797 & 60,380 & 0,417 \\
\hline Multidimensi & 54,860 & 54,836 & 0,024 \\
\hline
\end{tabular}




\section{KESIMPULAN DAN SARAN}

\section{Kesimpulan}

IPPKH menjadi salah satu sarana untuk menjembatani kepentingan perlindungan alam dan lingkungan sekitarnya serta kepentingan investasi, sehingga investasi di sektor pertambangan batubara tetap dapat dilakukan di kawasan hutan dengan syarat dan batasan tertentu agar kelestarian hutan tetap terlindungi. Seperti halnya saat ini, kondisi pengelolaan bentang alam pasca tambang batubara pada kawasan IPPKH di Kalimantan Timur yang dikelola oleh perusahaan tambang batubara dengan status usaha PKP2B, masuk dalam kategori status cukup berkelanjutan. Begitu pula dengan 5 parameter dimensi keberlanjutan, masingmasing dimensi masuk dalam kategori status cukup berkelanjutan, kecuali pada dimensi sosial budaya yang menunjukan status kurang berkelanjutan.

Sejumlah atribut dinilai sensitif (leverage attribute) bagi keberlanjutan pengelolaan bentang alam pasca tambang batubara pada kawasan IPPKH di Kalimantan Timur. Namun bila dipilah pada masing-masing dimensi keberlanjutan dengan standar nilai sensitivitas $(\mathrm{RMS}) \geq 1$, pada dimensi ekologi terdapat 2 atribut, dimensi ekonomi 3 atribut, dimensi sosial budaya 5 atribut, dimensi hukum dan kelembagaan 3 atribut, dimensi infrastruktur dan teknologi 9 atribut. Jumlah total atribut yang sensitif dari ke lima dimensi keberlanjutan adalah 22 atribut. Peningkatan keberlanjutan pengelolaan bentang alam pasca tambang batubara pada kawasan IPPKH di Kalimantan Timur dapat dilakukan dengan melakukan rutinitas pengawasan, intervensi kebijakan dan perbaikan kinerja, diutamakan pada atribut sensitif. Pemerintah perlu memiliki fokus yang jelas untuk mengubah menjadi lebih berkelanjutan, seperti: pemberdayaan masyarakat sekitar kawasan tambang batubara dan meminimalisasi tingkat kerusakan lingkungan, serta mengendalikan tingkat gangguan operasional pertambangan terhadap ekosistem hutan.

\section{Saran}

Penelitian ini menunjukkan kondisi saat ini (existing condition), oleh karena itu untuk melihat keberlanjutan pengelolaan bentang alam pasca tambang batubara pada kawasan IPPKH di masa yang akan datang perlu dilakukan analisis tambahan seperti analisis sistem dinamis yang dapat memberikan gambaran dinamika strategi pengelolaan bentang alam pasca tambang batubara pada kawasan IPPKH yang berkelanjutan di masa yang akan datang.

Perlu dilakukan upaya peningkatan nilai indeks keberlanjutan pengelolaan bentang alam pasca tambang batubara pada kawasan IPPKH di Kalimantan Timur dengan cara meningkatkan perhatian dalam mengelola 22 atribut sensitif terutama lima faktor dominan pada dimensi sosial budaya yang sangat berpengaruh pada keberlanjutan pengelolaan bentang alam pasca tambang batubara pada kawasan IPPKH.

Tetap meningkatkan fokus perhatian terhadap kebijakan pengendalian dan meminimalisasi tingkat gangguan pertambangan terhadap ekosistem, baik selama operasional maupun pasca tambang. Selain itu, konsistensi penegakan hukum atas pelanggaran ketentuan lingkungan dan kegiatan pembinaan masyarakat dalam rangka pemberdayaan dan kesejahteraan hidup masyarakat sekitar hingga level kemandirian oleh perusahaan tambang batubara.

\section{DAFTAR PUSTAKA}

Bangian, A. H., Ataei, M., Sayadi, A. dan Gholinejad, A. (2012) "Optimizing postmining land use for pit area in open-pit mining using fuzzy decision making method," International Journal of Environmental Science and Technology, 9(4), hal. 613-628. doi: 10.1007/s13762-012-0047-5.

Bidang Integrasi dan Diseminasi Statistik (ed.) (2018) Provinsi Kalimantan Timur dalam angka 2018. Samarinda: BPS Provinsi Kalimantan Timur.

Burchart-Korol, D., Krawczyk, P., Czaplicka-Kolarz, K., Turek, M. dan Borkowski, W. (2014) "Development of sustainability assessment method of coal mines," Journal of Sustainable Mining. Elsevier Masson SAS, 13(4), hal. 511. doi: $10.7424 /$ jsm 140402 .

Burchart-Korol, D., Fugiel, A., Czaplicka-Kolarz, K. dan Turek, M. (2016) "Model of 
environmental life cycle assessment for coal mining operations," Science of The Total Environment. Elsevier B.V., 562, hal. 61-72. doi: 10.1016/j.scitotenv.2016.03.202.

Daru, T. P., Pagoray, H. dan Suhardi (2016) "Pemanfaatan lahan pasca tambang batubara sebagai usaha peternakan sapi potong berkelanjutan," Ziraa'ah, 41(3), hal. 382-392. Tersedia pada: https://ojs.uniskabjm.ac.id/index.php/ziraah/article/view/543.

Direktorat Jenderal Mineral dan Batubara (2017) Statistik Minerba 2017. Jakarta: Direktorat Jenderal Mineral dan Batubara.

Dontala, S. P., Reddy, T. B. dan Vadde, R. (2015) "Environmental aspects and impacts its mitigation measures of corporate coal mining," Procedia Earth and Planetary Science. Elsevier B.V., 11, hal. 2-7. doi: 10.1016/j.proeps.2015.06.002.

Dubiński, J. (2013) "Sustainable development of mining mineral resources," Journal of Sustainable Mining, 12(1), hal. 1-6. doi: 10.7424/jsm130102.

Fauzi, A. dan Anna, S. (2005) Pemodelan sumber daya perikanan dan kelautan untuk analisis kebijakan. Jakarta: Gramedia Pustaka Utama.

Fauzi, H. (2007) “Perencanaan pembangunan hutan pada lahan bekas tambang batubara berbasis strategi kehutanan sosial," Jurnal Hutan Tropis Borneo, 08(20), hal. 33-45.

Huang, L., Zhang, P., Hu, Y. dan Zhao, Y. (2015) "Vegetation succession and soil infiltration characteristics under different aged refuse dumps at the Heidaigou opencast coal mine," Global Ecology and Conservation. Elsevier B.V., 4, hal. 255-263.

doi: 10.1016/j.gecco.2015.07.006.

Kavanagh, P. (2001) Rapid apraisal of fisheries (Rapfish) project: Rapfish softwere des eruption (for Microsoft Excel). University of British Columbia.

Kavanagh, P. dan Pitcher, T. J. (2004) Impelementasi microsoft exel software for rapfish: A technigue for the rapid appraisal of fisheries status, Fisheries Centre Research Reports. Vancouver.

Kementerian Lingkungan Hidup dan Kehutanan (2017) Statistik lingkungan hidup dan kehutanan tahun 2017. Diedit oleh Pusat Data dan Informasi. Jakarta: Kementerian Lingkungan Hidup dan Kehutanan.
Kemp, D., Worden, S. dan Owen, J. R. (2016) "Differentiated social risk: Rebound dynamics and sustainability performance in mining," Resources Policy. Elsevier, 50, hal. 19-26. doi: 10.1016/j.resourpol.2016.08.004.

Krawczyk, P., Majer, M. dan Krzemień, J. (2014) "The possibility of using cost benefit analysis (CBA) for calculating eco-efficiency of coal mines in Poland," Bezpieczeństwo Pracy $i$ Ochrona Środowiska w Górnictwie, 6(238), hal. 28-35.

Nababan, B. O., Sari, Y. D. dan Hermawan, M. (2017) "Analisis keberlanjutan perikanan tangkap skala kecil di Kabupaten Tegal Jawa Tengah (teknik pendekatan Rapfish)," Jurnal Sosial Ekonomi Kelautan dan Perikanan, 2(2), hal. 137-157. doi: 10.15578/jsekp.v2i2.5868.

Nurmalina, R. (2008) "Keberlanjutan sistem ketersediaan beras nasional: pendekatan teknik ordinasi rap-rice," Jurnal Agribisnis dan Ekonomi Pertanian, 2(2), hal. 65-88.

Pandey, B., Agrawal, M. dan Singh, S. (2014) "Coal mining activities change plant community structure due to air pollution and soil degradation," Ecotoxicology, 23(8), hal. 14741483. doi: 10.1007/s10646-014-1289-4.

Pitcher, T. J., Lam, M. E., Ainsworth, C., Martindale, A., Nakamura, K., Perry, R. I. dan Ward, T. (2013) "Improvements to Rapfish: A rapid evaluation technique for fisheries integrating ecological and human dimensionsa," Journal of Fish Biology, 83(4), hal. 865-889. doi: 10.1111/jfb.12122.

Pitcher, T. J. dan Preikshot, D. (2001) "Rapfish: A rapid appraisal technique to evaluate the sustainability status of fisheries," Fisheries Research, 49(3), hal. 255-270. doi: 10.1016/S0165-7836(00)00205-8.

Prasodjo, E., Sitorus, S. R. P., Pertiwi, S. dan Putri, E. I. K. (2015) "Analisis status keberlanjutan kegiatan pertambangan batubara di Kota Samarinda Provinsi Kalimantan Timur," Jurnal Teknologi Mineral dan Batubara, 11(1), hal. 49-60. Tersedia pada: http://jurnal.tekmira.esdm.go.id/index.php/mi nerba/article/view/241.

Ren-shu, Y., Guo-liang, Y., Yu-long, C. dan Qiang, T. (2011) "Coal subsided area land harmonious governance and suitability evaluation methods," Procedia Environmental Sciences, 10(PART B), hal. 1222-1227. doi: 10.1016/j.proenv.2011.09.196. 
Sierpińska, M. dan Bąk, P. (2012) "Financial structure of mining sector companies during an economic slowdown," Archives of Mining Sciences, 57(4), hal. 1089-1100. doi: 10.2478/v10267-012-0072-8.

Sierpińska, M. dan Bąk, P. (2013) "The role of corporate bonds in financing mining sector companies during an economic downturn," Gospodarka Surowcami Mineralnymi Mineral Resources Management, 29(1), hal. 141-155. doi: 10.2478/gospo-2013-0011.

Subagyo, P. J. (2006) Metode penelitian dalam teori dan praktek. Jakarta: Rineka Cipta.

Sukwika, T., Darusman, D., Kusmana, C. dan Nurrochmat, D. R. (2018) "Skenario kebijakan pengelolaan hutan rakyat berkelanjutan di Kabupaten Bogor," Jurnal
Pengelolaan Sumberdaya Alam dan Lingkungan (Journal of Natural Resources and Environmental Management), 8(2), hal. 207215. doi: 10.29244/jpsl.8.2.207-215.

Wibowo, A. B., Anggoro, S. dan Yulianto, B. (2015) "Status keberlanjutan dimensi ekologi dalam pengembangan budidaya air tawar di Kabupaten Magelang," Jurnal Saintek Perikanan, 10(2), hal. 107-113. Tersedia pada:

http://ejournal.undip.ac.id/index.php/saintek/ article/view/9330.

Widiatmaka, W., Munibah, K., Sitorus, S. R. P., Ambarwulan, W. dan Firmansyah, I. (2015) "Appraisal keberlanjutan multidimensi penggunaan lahan untuk sawah di Karawang Jawa Barat," Jurnal Kawistara, 5(2), hal. 99220. doi: 10.22146/kawistara.7591. 
